
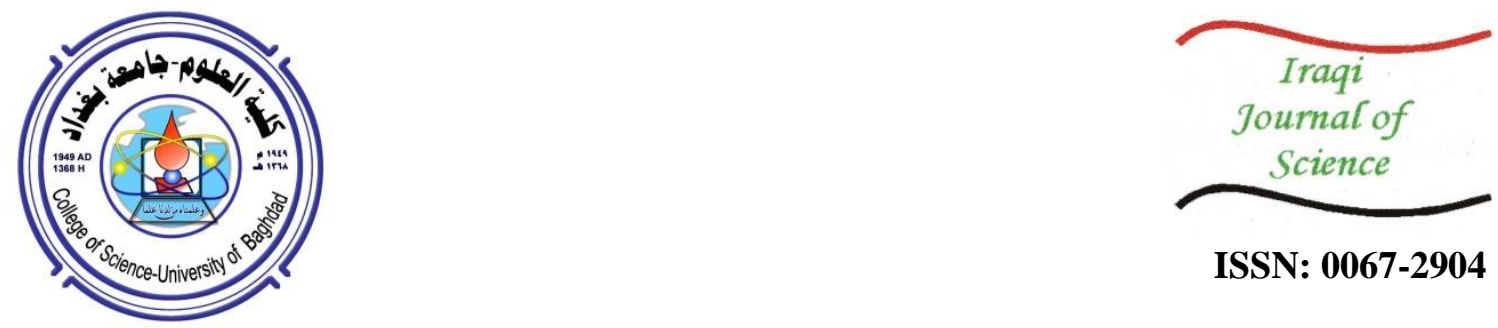

ISSN: 0067-2904

\title{
Assessing sediment pollution by applying some geochemical indices for Al- Wind River banks/ East of Iraq
}

\author{
Iman A. Al-Ali \\ Department of Geology, College of Science, University of Baghdad; Baghdad, Iraq
}

\begin{abstract}
15 sediment samples were collected; 8 samples from the eastern bank, and 7 samples from the western bank of Al-Wind River in Diyala governorate to assess the sediment pollution in some trace elements such as $\mathrm{Fe}, \mathrm{Ni}, \mathrm{Cd}, \mathrm{Zr}, \mathrm{Zn}$ and $\mathrm{Cu}$ in addition to some oxides such as $\mathrm{Al}_{2} \mathrm{O}_{3}, \mathrm{CaO}, \mathrm{Na}_{2} \mathrm{O}$ and $\mathrm{K}_{2} \mathrm{O}$ to find the effect of anthropogenic pollution and the industrial production on the sediment closed especially Naftkhana by using some geochemical pollution indices such as: geoaccumulation factor (I-geo), enrichment factor (EF),contamination factor (CF), pollution loud index (PLI) and to evaluate the degree of weathering by Applying the Chemical Index of Alteration (CIA)in both banks of Al-Wind River. The results of general contamination factors indicate that the eastern bank of Al-Wind River especially that closed by Naftkhana area having quite more concentrations of trace element and oxides from the western bank. The results of I-geo presents unpolluted sediment with $\mathrm{Pb}$ and $\mathrm{Fe}$ and slightly polluted with $\mathrm{Zn}, \mathrm{Cu}$, and $\mathrm{Ni}$ in both banks, while the western bank in some locations recorded of moderately polluted sediments with $\mathrm{Ni}$ and slightly to moderately polluted sediments with $\mathrm{Cu}$ and $\mathrm{Zn}$ and reach moderately severely polluted in the eastern bank. The contamination factor (CF) for $\mathrm{Ni}$ and $\mathrm{Zr}$ classified as class 2 which indicate moderately contamination to severely pollute in both banks, while $\mathrm{Fe}, \mathrm{Pb}, \mathrm{Cu}$ and $\mathrm{Zn}$ conbankred unpolluted in both banks. Enrichment factor (EF) for $\mathrm{Fe}, \mathrm{Pb}, \mathrm{Zr}$ and $\mathrm{Cu}$ are conbankred deficiency to low enrichment the range of natural variability, while $\mathrm{Ni}$ record high values reached to 6.4 indication of anthropogenic inputs. Pollution load Index (PLI) is perfection and classified as class 0 in both banks. Chemical index of alteration (CIA) reflecting the chemical weathering intensity especially for the western bank.
\end{abstract}

Keywords: Geo-accumulation; Contamination factor; Pollution load index; Chemical Index, Enrichment factor, Al-Wind River, East of Iraq.

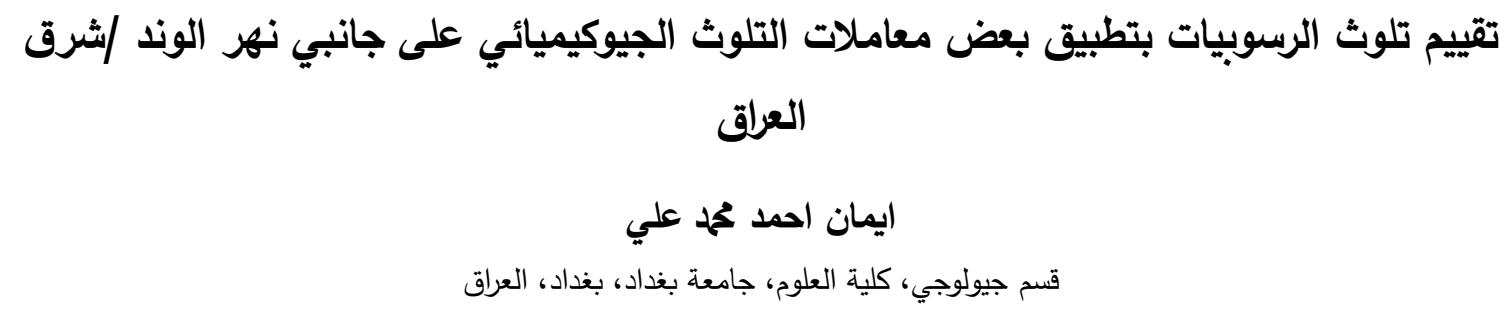

$$
\begin{aligned}
& \text { الخلاصة } \\
& \text { تم جمع } 15 \text { نموذجا رسوبيا من ضفتي نهالوند } 8 \text { من الضفة الثرقية و7 من الضفة الغربية من نهر } \\
& \text { الوند في محافظة ديالى لتقييم تلوث التربة ببعض العناصر الثقيلة مثل الحديدوالنيكل والكاديميوم والزركون }
\end{aligned}
$$

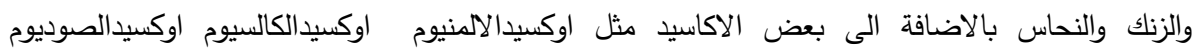

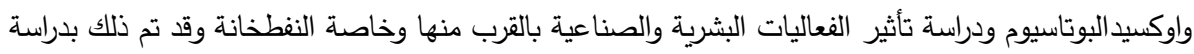

Email: mahammedrahman842004@gmail.com 


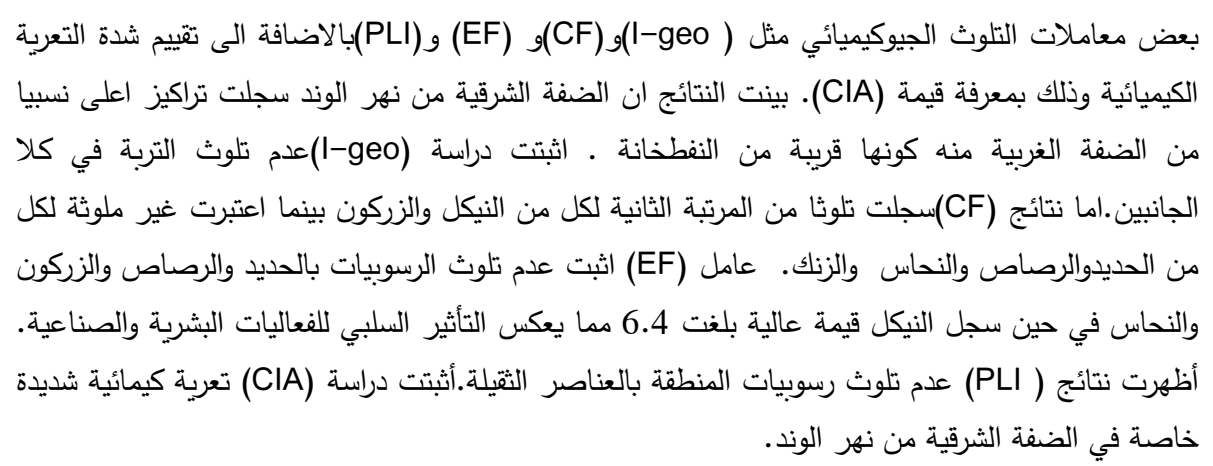

\section{INTRODUCTION}

The anthropogenic and the industrial components both represent the main cause of River sediment pollution [1].The common chemicals that causing sediment pollution are: Petroleum hydrocarbons, heavy metals, pesticides, solvents [2]. Many researchers have used many traditional analytical methods to find the pollution in sediments $[3,4]$ while few of them used the chemical indices like accumulation load index (I-geo), enrichment factor (EF), contamination factor (CF), and pollution load index (PLI) together to assess the pollution in sediment. Trace elements are found in natural soil in a small amounts and its concentration increased in the environment due to human activities and may reach to concentrations up to levels lethal to humans and wildlife both in water pollution or its accumulation in aqueous solutions, medium soil texture helps in contaminants movement to the surface and ground water, therefore; it becomes subject to the chemical and physical processes [5].There are four anthropogenic sources for trace elements in the soil; the first is atmospheric deposition that arising from coal and gasoline burning, nonferrous and ferrous metal mining, smelting, manufacturing, waste ignition, production of phosphate fertilizers, cement, and wood combustion; the second is the land application of sewage sludge, animal manure and other organic wastes and coproducts from agriculture and food industries; the third is land disposal of industrial co-products and waste, including paper industry sludge, coal fly ash, bottom fly ash and wood ash; the fourth source for heavy metals in the soil is fertilizers, lime and agrochemicals such as pesticides that used in agriculture activates [6].Trace elements can be found in many forms: as soluble in sediment solution, exchangeable in organic and inorganic components, or as structural components of the lattices of sediment minerals, or as insoluble precipitates with other sediment components as complexes. High concentrations of heavy metals in soil reflect the occurrence of mixture material inputs from different sources. In an arid environment such in the study area; physical weathering usually occurs in high rates, while chemical transformation being rather rare because it requires a lot of water, while in a tropical climate environments with high temperature and humidity, chemical weathering is favored, resulting in the formation of more clay minerals [7].

The main aim of this research is to compute and compare the trace elements distribution of some trace elements such as $\mathrm{Fe} \mathrm{Ni}, \mathrm{Cu}, \mathrm{Zr}, \mathrm{Zn}, \mathrm{pb}$ and $\mathrm{Cd}$ by using many chemical indices like geo-accumulation index (I-geo), contamination factor (CF), enrichment factor (EF) and Pollution load index (PLI) and study the effect of Nafkhana on the soil quality in the study area, and find the percentage of some oxides such as $\mathrm{Al}_{2} \mathrm{O}_{3}, \mathrm{CaO}, \mathrm{Na}_{2} \mathrm{O}$ and $\mathrm{K}_{2} \mathrm{O}$ to investigate the intensity of chemical weathering by applying the CIA in both banks of Al-Wind River in Khanaqeen area/ Diyala Governorate .

\section{Location of the study area}

The study area is located in the northeastern part of Iraq at the northeastern part of Diyala provinces between latitudes $\left(34^{\circ} 14^{\prime} 00^{\prime \prime}-34^{\circ} 16^{\prime} 00^{\prime \prime}\right) \mathrm{N}$ and longitude $\left(45^{\circ} 10^{\prime} 40^{\prime \prime}-45^{\circ} 30^{\prime} 00^{\prime \prime}\right) \mathrm{E}$, Sediment samples are collected during September, 2016 from different sites of Al-Wind River; samples D1, D2, D3, D4, D5, D6 and D7 are from the western bank, while the sediment samples D8, D9, D10, D11, D12, D13, D14 and D15 are from the eastern bank that nearby Naftkhana area (Figure-1) 


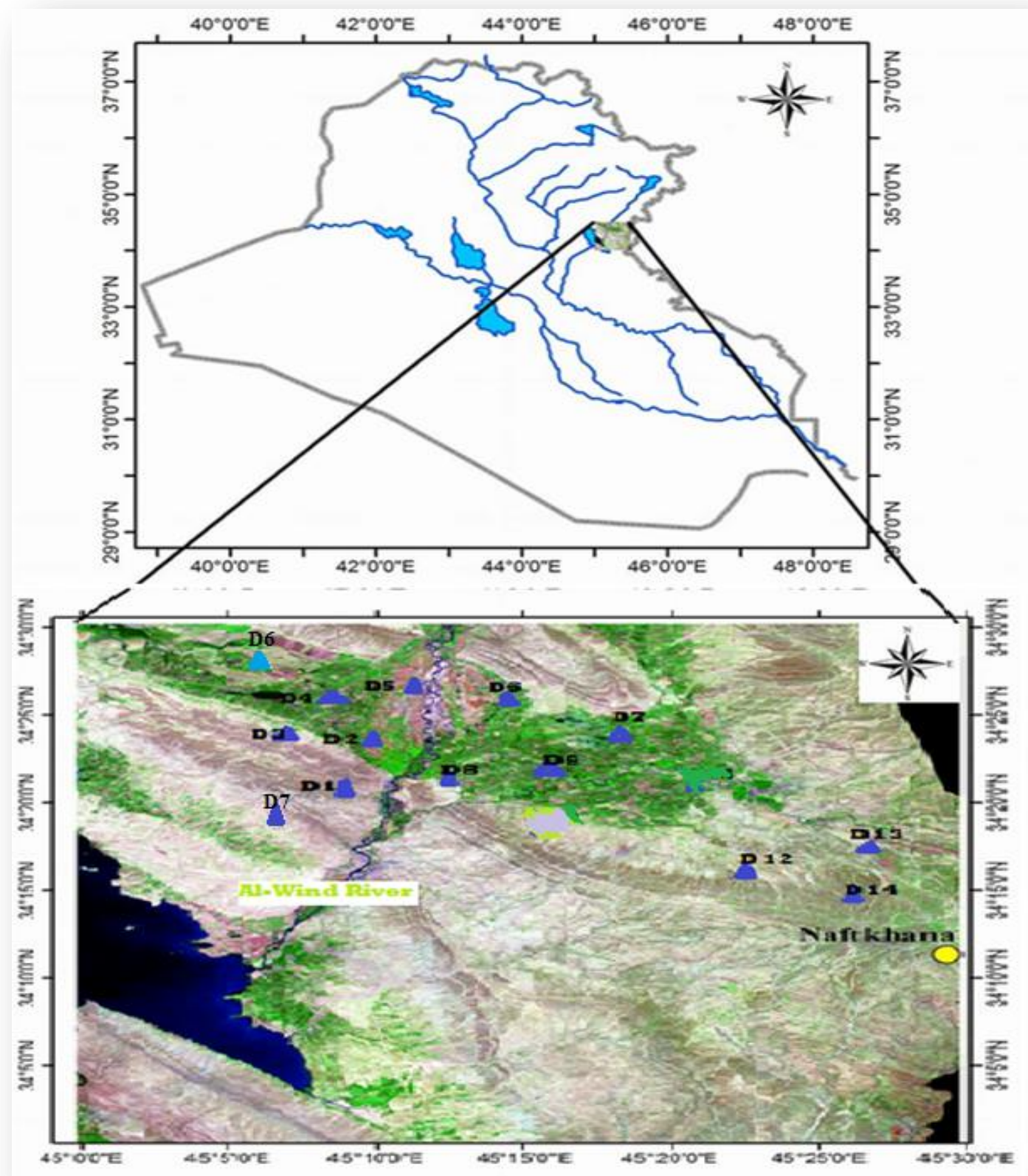

Figure 1-Location map for the study area viewing the water sampling sites

Table1-The concentrations of heavy elements $(\mathrm{mg} / \mathrm{kg})$, Percentage of oxides and CIA values measured in the study area,

\begin{tabular}{|c|c|c|c|c|c|c|c|c|c|c|c|c|}
\hline Bank & $\begin{array}{l}\text { Site } \\
\text { No. }\end{array}$ & $\mathbf{F e}$ & $\mathbf{P b}$ & $\mathbf{Z r}$ & $\mathbf{N i}$ & $\mathbf{Z n}$ & $\mathbf{C u}$ & $\begin{array}{c}\mathbf{A l}_{2} \mathbf{O}_{3} \\
\end{array}$ & $\begin{array}{c}\mathrm{CaO} \\
\%\end{array}$ & $\mathrm{Na}_{2} \mathrm{O} \%$ & $\begin{array}{c}\mathbf{K}_{2} \mathbf{O} \\
\%\end{array}$ & CIA \\
\hline \multirow{9}{*}{$\begin{array}{l}\text { Wester } \\
\text { n bank }\end{array}$} & D1 & 1665 & 7.2 & 44 & 88 & 98 & 13.1 & 5.33 & 14.2 & 4.5 & 1.02 & 21.3 \\
\hline & D2 & 2015 & 8.6 & 40 & 92 & 78 & 12.4 & 6.11 & 15.1 & 3.8 & 1 & 23.5 \\
\hline & D3 & 3420 & 7.9 & 43 & 100 & 87 & 11.4 & 5.8 & 14.9 & 4.3 & 1.2 & 22.1 \\
\hline & D4 & 1540 & 9.2 & 40 & 76 & 78 & 13.7 & 4.82 & 13 & 3.9 & 0.9 & 21.3 \\
\hline & D5 & $\mathbf{3 3 4 5}$ & 11.7 & 44 & 94 & 68 & 17.8 & 7.3 & 14.5 & 4.1 & $\mathbf{0 . 8 9}$ & 27.3 \\
\hline & D6 & 3321 & 8.2 & 45 & 84 & 89 & 14.5 & 4.2 & 13.9 & 4.3 & 1.1 & 17.8 \\
\hline & D7 & 2370 & 9.9 & 44 & 89 & 122 & 12.7 & 6.7 & 15.8 & 4.2 & 1 & 24.1 \\
\hline & Av. & 2525 & 8.95 & 42.8 & 89 & 88.5 & 13.6 & 5.75 & 14.4 & 4.12 & 1.01 & 22.4 \\
\hline & D8 & 4355 & 12.5 & 49.8 & 122 & 133 & $\mathbf{1 5 . 8}$ & 6.8 & 16 & 4.8 & 1.6 & 26.9 \\
\hline
\end{tabular}




\begin{tabular}{|c|c|c|c|c|c|c|c|c|c|c|c|c|}
\hline \multirow{8}{*}{$\begin{array}{l}\text { Easter } \\
\text { n bank }\end{array}$} & D9 & 4210 & 11.8 & 52 & 110 & 90 & 16.5 & 5.55 & 15.3 & 4.4 & 1.5 & 20.5 \\
\hline & D10 & 5730 & 16.9 & 55 & 119 & 117 & 24.2 & 7.21 & 17.1 & 4.9 & 1.2 & 23.4 \\
\hline & D11 & 5321 & 17.3 & 56 & 104 & 92 & 21.9 & 7.10 & 15.2 & 4.9 & 1.2 & 25.3 \\
\hline & D12 & 5318 & 14.2 & 58 & 118 & 112 & 22.2 & 5.23 & 14.8 & 5.1 & 1.5 & 19.6 \\
\hline & D13 & $\mathbf{5 3 3 0}$ & 16.9 & 63 & 120 & 115 & 19.3 & 4.76 & 16.7 & 5.4 & 1.3 & 36.2 \\
\hline & D14 & 5750 & 15.9 & 61 & 116 & 100 & 21.6 & 5.21 & 16.8 & 5.6 & 1.5 & 17.9 \\
\hline & D15 & 5266 & 16.6 & 61.3 & 128 & 120 & 22.9 & 6.23 & 15.5 & 4.7 & 1.61 & 22.2 \\
\hline & Av. & 5160 & 15.2 & 57 & 107.1 & 109 & 20.5 & 6 & 15.9 & 5.1 & 1.4 & 24 \\
\hline \multicolumn{2}{|c|}{$\begin{array}{l}\text { Al- Bassam } \\
\text { and Yousif, } \\
2013\end{array}$} & & 6.02 & & 91 & 54 & 16 & & & & & \\
\hline
\end{tabular}

\section{MATERIALES AND METHODS}

15 sediment samples were selected at depths $0-30 \mathrm{~cm}$ during September 2016.7 samples from the western bank of Al-Wind River and 8 samples from the eastern bank. All the sediment samples were powdered, then subjected to the drying process by oven at a temperature of $60^{\circ} \mathrm{C}$. Then $5 \mathrm{~g}$ powder of size $0.063 \mu \mathrm{m}$ was analyzed in XRF Spectrometer to find out the element concentrations. Studying trace elements concentration of soil particles of clay fragments size particles less than 2 microns because they contain high concentrations of trace elements and it has high adsorption capability of these elements in the environment. All samples have been analyzed for $\mathrm{Fe}, \mathrm{Pb}, \mathrm{Zr}, \mathrm{Zn}, \mathrm{Cu}$ and $\mathrm{Ni}$ elements using four indices; geo-accumulation index (I-geo), contamination factor (CF), enrichment factor (EF) and pollution load index (PLI) to detected the sediments pollution. The results were established according to [8]. All samples were analyzed in geology department laboratories, College of Science, University of Baghdad. Oxides were analyzed to find the intensity of weathering by computing the chemical index of alteration (CIA) by using [9] formula as follow:

$\mathrm{CIA}=\left(\mathrm{Al}_{2} \mathrm{O}_{3} / \mathrm{Al}_{2} \mathrm{O}_{3}+\mathrm{CaO}+\mathrm{Na}_{2} \mathrm{O}+\mathrm{K}_{2} \mathrm{O}\right) \times 100$

\section{RESULTS AND DISCUSSION}

Mean concentrations of 6 trace elements analysis were in the order of following: $\mathrm{Ni}>\mathrm{Zn}>\mathrm{Cu}>\mathrm{Pb}$ $>\mathrm{Fe}>\mathrm{Zr}$ and four oxides includes $\mathrm{CaO}>\mathrm{Al}_{2} \mathrm{O}_{3}>\mathrm{NaO}>\mathrm{K}_{2} \mathrm{O}$. As it is clear, the concentrations of most elements measured in the sediments of the eastern bank of Al-Wind River especially that nearby Naftkhana are record higher rates concentration from that recognized in the western bank (Table-1). Brief Discussion of the heavy metals and oxides concentrations is bellow:

\section{A Heavy Metals}

4. A.1 Nickel (Ni): is available in the oxidation acidic environment, it has symmetrical characters with $\mathrm{Cu}$ and $\mathrm{Cd}$ [10]. Its concentration depends on the abundance of organic matter and clay minerals [11]. In sediments, $\mathrm{Ni}$ is slightly mobile it's mainly occur in the residual fraction in over of $50 \%$ of its total contents in loamy sandy sediment, and in about $70 \%$ of its occurrence in estuary muck [12]. Ni concentration in The concentrationsediment of the west bank of Al- Wind River ranges between (76 $100 \mathrm{ppm})$ with average $(89 \mathrm{ppm})$, while in the east bank that closed to Naftkhana ranges between (104- 128) ppm with average (107.1 ppm) (Table-1).

4. A.2 Zinc (Zn): Many sources may originate an anthropogenic $\mathrm{Zn}$ in agricultural sediments such as atmospheric deposition, fertilizers, pesticides, sewage sludge, manure, waste depending on its chemical species and their affinity to sediment and sediment parameters [13]. The concentration of $\mathrm{Zn}$ ranges between (68-122) ppm with an average of $(88.5 \mathrm{ppm})$ in the western bank of Al-Wind River, while in the eastern bank ranges between (90-133) ppm with average (109 ppm) (Table-1).

4. A.3 Copper $(\mathbf{C u})$ : is so transitional at $\mathrm{pH}<5.5$ and becomes with a little transitional at solution basal or equal [14]. Common value for the average total $\mathrm{Cu}$ contents in sediments of different types all over the world is reported to range between 20 and $30 \mathrm{mg} / \mathrm{kg}$ [15]. The concentration of $\mathrm{Cu}$ in the western bank of Al- Wind River ranged between (13.4- 17.8) ppm with average of (13.65 ppm), and it ranged (15.8- 24.2) ppm with average (20.5 ppm) in the east bank (Table-1).

4. A.4 Iron (Fe): Iron is one of the major constituents of the lithosphere, so it plays a vital role in the behavior of several heavy elements, the range of $\mathrm{Fe}$ contents in sediments is between $0.1-10 \%$. Contents of $\mathrm{Fe}$ in sediments are innate from parent materials and/or resulted from sediment processes that are controlled by climatic factors[7].In sediments, Fe occurs mainly in forms of oxides and hydroxides, as amorphous compounds, small particles, fillings in cracks and veins and coatings on 
other minerals or particles. In sediments, Fe occurs mainly in forms of oxides and hydroxides, as amorphous compounds, small particles, fillings in cracks and veins and coatings on other minerals or particles [16]. Concentration of Fe in the western bank of Al-Wind River ranged between (1665-3420) ppm with average of $(2525 \mathrm{ppm})$, while in the eastern bank ranged between (4210- 5750) ppm with average $5160 \mathrm{ppm}$ ( Table-1).

4. A.5 Lead (Pb): is one of four metals that have the most damaging effects on human health. It can enter the human body through the uptake of food (65\%), water $(20 \%)$ and air $(15 \%)$ [17]. The concentration of $\mathrm{Pb}$ in the western bank of Al-Wind River ranged between (7.2-11.7) ppm with average of $(8.9 \mathrm{ppm})$, while in the eastern bank ranged between (11.8- 17.3) ppm with average (15.2 ppm)( Table-1).

4. A.6 Zirconium $\mathrm{Zr}$ : is conbankred slightly mobile in soil, the main transporting agents for its mobility is organic acids [18]. It is noted that the average concentration of $\mathrm{Zr}$ in the east bank ranged between (49.8- 63) ppm with average (57) ppm slightly higher than the west bank that ranged between (40- $45 \mathrm{ppm}$ ) with average of (42.8) ppm. (Table-1)

\section{B Oxides:}

4. B.1 $\left(\mathrm{Al}_{2} \mathrm{O}_{3}\right)$ Aluminum oxide: The concentration of $\mathrm{Al}_{2} \mathrm{O}_{3}$ in sediment is depended on parent material, degree of weathering, depletion processes. Aluminum is present in the opaque minerals, and in the clay minerals structure such as chlorite, montmorillonite and kaolinite minerals [19]. $\mathrm{Al}_{2} \mathrm{O}_{3}$ percentage in the western bank of Al- Wind River ranged between (4.2-7.35\%) with average of 5.75\%, while the east bank ranged between (4.7-7.2\%) with average of 6\% (Table-1).

4. B.2 Calcium oxide (CaO): $\mathrm{CaO}$ percentage ranged between (13-15.8\%) in the western bank of AlWind River with an average $14.4 \%$, and from (14.8-17.1\%) with an average of $15.9 \%$ in the eastern bank (Table-1).

4. B.3 Sodium Oxide $\left(\mathrm{Na}_{2} \mathrm{O}\right)$ : Sodium oxide content in sediment combines with clay minerals especially Montmorillonite [20]. $\mathrm{Na}_{2} \mathrm{O}$ percentage ranged between $(3.8-4.5 \%)$ with an average of $4.12 \%$ in the west bank, while it ranged between (4.4- 5.6\%) with an average of 5.1\% in the east bank of Al-Wind River (Table-1).

4.B.4 Potassium Oxide $\left(\mathrm{K}_{2} \mathbf{O}\right)$ : The percentage of the western bank of Al-Wind River Ranged between $(0.9-1.2 \%)$ with an average of $1.01 \%$, while it ranged between(1.2- 1.61\%) with an average of $1.4 \%$ in the east bank of Al-Wind River, the high oxide percentage reflects the negative effect of Naftkhana on the sediment closed (Table-1).

\section{C Geochemical Indices:}

All the results of geochemical are listed in Table-6. Discussion of these chemical indices as follows:

\section{C.1 Geo-accumulation index (I- geo):}

In order to compare the analyzed heavy elements in the study area with background levels I- geo can be calculated according to [8] by this equation:

I- geo $=\log _{2}(\mathrm{Cn} / 1.5 \mathrm{Bn})$

$\mathrm{Cn}$ : concentration of the heavy metals in the sediments of the study area.

$\mathrm{Bn}$ : concentration of heavy metals in the sediment of the background.

The standard of I- geo categories were classified the sediment into six classes [20] (Table-2). I- geo for $\mathrm{Fe}$ was negative in both banks; ranged between $(-0.39$ to -0.73$)$ with an average $(-0.54)$ in the western bank, while they ranged between $(-0.16$ to -0.44$)$ with an average $(-0.24)$ in the eastern bank indicate that both banks are unpolluted by each of $\mathrm{Fe}, \mathrm{Ni}, \mathrm{Zn}, \mathrm{Zr}$ and $\mathrm{Cu}$ although they have positive values in some sites but their values not exceed 1 that mean it was practically polluted to slightly polluted sediments Tables- $(2,6)$. 
Table 2-The main classes of the sediments according to I-geo values [21]

\begin{tabular}{|c|c|c|}
\hline I-geo & order & Result \\
\hline$\leq 0$ & class 0 & Practically unpolluted \\
\hline $0<$ to $\leq 1$ & class 1 & slightly polluted \\
\hline $1<$ to $\leq 2$ & class 2 & moderately polluted \\
\hline $2<$ to $\leq 3$ & class 3 & Severely polluted \\
\hline $3<$ to $\leq 4$ & class 4 & Severely extremely Polluted \\
\hline $4<$ to $\leq 5$ & class 5 & Extremely polluted \\
\hline$>5$ & class 6 & \\
\hline
\end{tabular}

4. C.2 Contamination factor (CF) has been computed according to [8] equation.

$\mathrm{CF}=\mathrm{Cn}$ Sample/ Cn Background

CF: contamination factor.

Cn (Sample): the concentration of metal content in the sample.

$\mathrm{Cn}$ (Background): the concentration of the background level of metal.

According to [20]) (Table-3), there are 3 classes of contamination factor, each of $\mathrm{Fe}, \mathrm{Cu}, \mathrm{Zr}$ elements are having $\mathrm{CF}<1$ therefore it represents low contamination so as $\mathrm{Pb}$ element in the eastern bank of $\mathrm{Al}$ Wind River; while $\mathrm{Pb}$ in the western bank represent class 2 so as $\mathrm{Ni}$ and $\mathrm{Zn}$ elements Tables- $(3,6)$.

Table 3-The main class of the sediments according to CF values [20]

\begin{tabular}{|c|c|c|}
\hline $\mathrm{CF}$ & class & Quality \\
\hline$<1$ & class 1 & Low contamination \\
\hline $1 \leq \mathrm{CF}<3$ & class 2 & Moderate contamination \\
\hline $3 \leq \mathrm{CF} \leq 6$ & class 3 & Considerable contamination \\
\hline
\end{tabular}

\section{C. 3 Pollution load index (PLI)}

Pollution load index (PLI) has been computed according to [21] equation:

$\mathrm{PLI}=\mathrm{n} \sqrt{\mathrm{CF}} 1 * \mathrm{CF} 2 * \mathrm{CF} 3 \times \ldots . . \mathrm{CF} \mathrm{n}$

$\mathrm{n}$ : number of metals has been analyzed.

$\mathrm{CF}$ : contamination factor

Pollution load index (PLI) for studied trace elements indicated that the soil classified as class 0 according to [21], all the sediments samples quality were classified as perfection (Table-4) that mean there is no local pollution. PLI value in the study area ranged from 0.32 to 0.49 with an average of 0.35 in the western bank and from 0.40 to 0.74 with average of 0.54 in the eastern bank Tables- $(4,6)$.

Table 4-The main class of the sediments according to PLI values [21]

\begin{tabular}{|c|c|c|}
\hline$<1$ & class 0 & Perfection \\
\hline$=1$ & class 1 & Baseline level \\
\hline$>1$ & class 2 & Deterioration site \\
\hline
\end{tabular}

\section{C .4 Enrichment Factor (EF)}

It represents a powerful instrument for analyzing sediment pollution, and transmission the raw environmental information to the searchers, managers and technicians [22]. To evaluate the source of 
the chemical elements; EF has shows for all sediment samples using Zircon ( $\mathrm{Zr}$ ) as a background element. Zircon careful as originated from natural lithogenic sources such as rock weathering contain Zircon bebank it has no significant anthropogenic source it used in geochemical studies of mineral weathering as a 'conservative' lithogenic element, bebank which comparative enrichments have been compared, the $\mathrm{EF}$ has been calculated according to the following equation [23]:

$\mathrm{EF}=(\mathrm{M} / \mathrm{Zr})$ sediment/(M / Zr)earth's crust. $\quad \ldots \quad$ (Zr is a background $)$.

M: Total elemental concentration $(\mathrm{mg} / \mathrm{kg})$

$\mathrm{Zr}$ : Total concentration of $\mathrm{Zr}(\mathrm{mg} / \mathrm{kg})$ in sediment sample/earth's crust.

According to [24- 26]; $\mathrm{EF}$ of $\mathrm{Fe}, \mathrm{Pb}$ and $\mathrm{Cu}$ elements is < 2; therefore their quality is deficiency to low enrichment the range of natural variability. The EF of Ni ranging between (4.1-5.1) with average of 4.4 in the eastern bank, while it's ranging between (4.4- 5.1) with an average of 4.7in the western bank, and its quality is low enrichment that almost caused by anthropogenic inputs, there is a significant enrichment in Zn element caused by anthropogenic inputs in sediment sample D1, D7and D8 which indicate human influence Tables - $(5,6)$.

Table 5-The main class of the sediments according to EF values [23-26]

\begin{tabular}{|c|c|}
\hline EF value & Quality \\
\hline $\mathrm{EF}<2$ & deficiency to low enrichment the range of natural variability \\
\hline $2<\mathrm{EF}<5$ & low enrichment (almost caused by anthropogenic inputs \\
\hline $5<\mathrm{EF}<20$ & $\begin{array}{c}\text { indication of human influence (significant enrichment caused by anthropogenic } \\
\text { inputs) }\end{array}$ \\
\hline $\mathrm{EF} 20$ to 40 & very high enrichment \\
\hline
\end{tabular}

4.C.5 Chemical Index of Alteration (CIA) has been measured according to [9] equation: CIA= $\left[\mathrm{Al}_{2} \mathrm{O}_{3} /\left(\mathrm{Al}_{2} \mathrm{O}_{3}+\mathrm{CaO}+\mathrm{Na}_{2} \mathrm{O}+\mathrm{K}_{2} \mathrm{O}\right) \times 100\right]$

the results are listed in (Table-1). By comparing the concentrations of trace elements in this study with those obtained of [27] in their study of Mesopotamian sediment (Table-1), it's noticed that all traces are within the acceptable range except $\mathrm{Zn}$ element that record high ranges from Al-Bassam and Yousif study. The high concentration of $\mathrm{Zn}$ element in the study area reflects the extensive use of fertilizers, so the Iraqi fertilizers rich in Zinc element [27].

\section{CONCLUSION}

- Geochemical analysis shows that the soil sample contains a high concentration of Zn element which exceeds the natural limits of Iraqi soil, this refers to the extensive use of fertilizers, the other trace elements were within the natural limits.

By comparing the concentrations of trace element with the previous study of Al-Bassam and Yousif concluded that all traces in the western bank of Al- Wind River were within the acceptable ranges except $\mathrm{Zn}$ element, while its values it's the standards in the eastern bank that record higher ranges this reveals the negative effect of the industrial activities.

- The spatial extent of pollution that examined in the area nearby Naftkhana reflects the negative effect of the industrial and anthropogenic process on the sediment. 
Table 6- I- geo, CF, EF and PLI values for sediment in the study area

\begin{tabular}{|c|c|c|c|c|c|c|c|c|c|c|c|c|c|c|c|c|c|c|c|}
\hline \multirow[t]{2}{*}{ location } & \multirow{2}{*}{$\begin{array}{l}\dot{z} \\
\dot{0} \\
\dot{n}\end{array}$} & \multicolumn{3}{|c|}{$\mathrm{Fe}$} & \multicolumn{3}{|c|}{$\mathrm{pb}$} & \multicolumn{2}{|c|}{$\mathrm{Zr}$} & \multicolumn{3}{|c|}{$\mathrm{Ni}$} & \multicolumn{3}{|c|}{$\mathrm{Zn}$} & \multicolumn{3}{|c|}{$\mathrm{Cu}$} & \multirow{2}{*}{$\begin{array}{c}\text { PL } \\
\text { I }\end{array}$} \\
\hline & & 己 & $\frac{5}{|r|}$ & 总 & 至 & 空 & مانّ & 乩 & 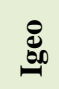 & 贸 & 空 & 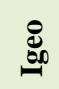 & 芘 & 空 & 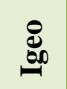 & 至 & 空 & 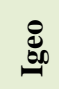 & \\
\hline \multirow{7}{*}{ 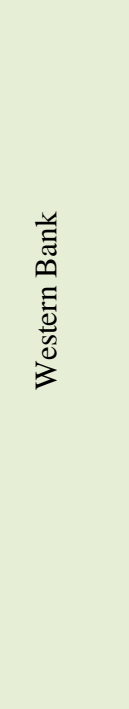 } & $\bar{\theta}$ & 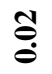 & 7 & $\stackrel{8}{\stackrel{s}{*} .}$ & $\stackrel{n}{8}$ & ָָี & $\stackrel{F}{\circ}$, & ণัఝ & 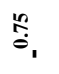 & $\fallingdotseq$ & $\stackrel{+}{+}$ & $\stackrel{9}{\circ !}$ & \pm & $\begin{array}{l}\text { ị̂ } \\
\text { in }\end{array}$ & $\stackrel{\Xi}{\dot{\theta}_{1}}$ & ชี & 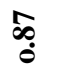 & ڤે. & $\stackrel{\text { fa }}{0}$ \\
\hline & ลิ & $\stackrel{0}{\stackrel{0}{\circ}}$ & $\frac{ \pm}{\theta}$ & کֶّ & $\stackrel{\mathscr{0}}{\circ}$ & 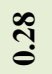 & $\stackrel{m}{\stackrel{m}{i}}$ & さ્ & î̀ & $\underset{\overbrace{}}{\overparen{Z}}$ & $\overrightarrow{i n}$ & $\stackrel{\infty}{\stackrel{0}{0}}$ & $\exists$ & $\underset{\stackrel{+}{\vec{t}}}{\vec{t}}$ & $\stackrel{1}{\stackrel{c}{c}}$ & ָุ & $\stackrel{\varrho}{0}$ & 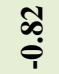 & m) \\
\hline & อิ & $\stackrel{0}{\circ}$ & กึ & क्: & $\stackrel{8}{:}$ & $\stackrel{\overbrace{}}{\leftrightarrow}$ & s. & $\stackrel{\text { ָூ }}{\text { }}$ & 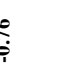 & $\stackrel{m}{\dddot{r}}$ & $\frac{10}{10}$ & $\stackrel{\text { on }}{: !}$ & 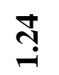 & $\stackrel{\infty}{+}$ & $\stackrel{\infty}{\stackrel{0}{i}}$ & ণ్రి & $\stackrel{\infty}{\stackrel{0}{0}}$ & 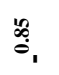 & 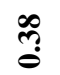 \\
\hline & t & $\stackrel{\tilde{\Theta}}{0}$ & กี & : & $\stackrel{\overbrace{}}{0}$ & ঙ్రి & s. & İ & ڤ્ڤ & $\vec{\sigma}$ & $\stackrel{\text { พ }}{*}$ & $\stackrel{5}{i}$ & $\exists$ & $\stackrel{m}{\rightarrow}$ & $\stackrel{2}{\leftrightarrow:}$ & $\stackrel{\mathbb{n}}{0}$ & $\stackrel{\overbrace{}}{\overbrace{}}$ & F. & 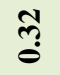 \\
\hline & 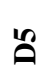 & $\stackrel{0}{0}$ & สี & 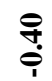 & $\mathscr{8}$ & क्ष & \begin{tabular}{l} 
C̆ \\
\multirow{i}{*}{}
\end{tabular} & ֻัँ & $\stackrel{n}{\stackrel{n}{i}}$ & $\stackrel{\text { In }}{\rightarrow}$ & $F$ & ب̣̂ & $\hat{s}$ & $\ddot{\dot{m}}$ & $\stackrel{\infty}{\frac{\infty}{i}}$ & లై & গี & بْبّ & $\stackrel{\text { ? }}{\circ}$ \\
\hline & ๑̊ & $\stackrel{\text { of }}{\circ}$ & तె & $\stackrel{f}{\stackrel{9}{i}}$ & $\stackrel{6}{6}$ & กึ? & $\stackrel{n}{\dddot{\leftrightarrow}}$ & స̂ & 菅 & $\cong$ & $\bar{F}$ & $\frac{m}{i}$ & $\stackrel{\cong}{\cong}$ & $\begin{array}{l}\vec{b} \\
\dot{+}\end{array}$ & 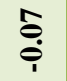 & ঙ̆ & $\stackrel{\circ}{\circ}$ & 点 & ले \\
\hline & $\hat{\theta}$ & $\stackrel{\Xi}{\circ}$ & $\stackrel{\text { สุ }}{8}$ & in & $\stackrel{\hat{\vartheta}}{\hat{\theta}}$ & స్ & 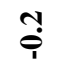 & ঙ̆丶 & $\hat{i}$ & $\stackrel{\infty}{=}$ & $\stackrel{+}{\dot{*}}$ & $\overline{\dot{i}}$ & $\underset{I}{\stackrel{5}{-}}$ & 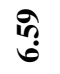 & 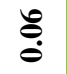 & $\stackrel{\overbrace{}}{\tilde{s}}$ & 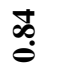 & $\stackrel{\leftrightarrow}{\stackrel{\leftrightarrow}{i}}$ & $\stackrel{\vec{q}}{\circ}$ \\
\hline Aver. & & 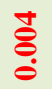 & $\frac{2}{8}$ & مै & ז̊ & 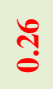 & 仓̊? & กี & ڤ̊ & $\stackrel{\infty}{=}$ & f) & ị & 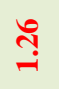 & $\underset{+}{\stackrel{\varpi}{+}}$ & $\stackrel{5}{0}$ & İ & $\stackrel{\leftrightarrow}{\circ}$ & î & ल류. \\
\hline \multirow{8}{*}{ 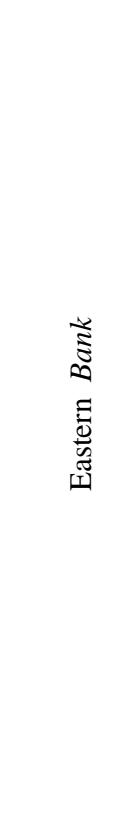 } & $\stackrel{\infty}{\varrho}$ & $\stackrel{0}{0}$ & "ู & $\stackrel{m}{1}$ & - & $\stackrel{\overbrace{}}{0}$ & $\stackrel{\text { ְ̆ }}{1}$ & ల్తి & $\hat{i}$ & 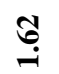 & $\stackrel{\overrightarrow{0}}{i}$ & $\stackrel{\overbrace{}}{8}$ & 9 & 3 & $\stackrel{\tilde{\Xi}}{\stackrel{0}{0}}$ & స్ํ & $\tilde{s}$ & $\stackrel{\text { ঙ̊ }}{8}$ & กิ \\
\hline & ิิ & $\stackrel{+}{\stackrel{5}{G}}$ & กึ่ & ల్ల్ & ă & तु่ & ్ָరి & $\bar{m}$ & مب & $\stackrel{巳}{\sharp}$ & ఫే & 0 & $\stackrel{\infty}{\dddot{I}}$ & 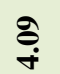 & 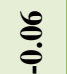 & సิ & $\stackrel{8}{0}$ & فे̣ & f̊ \\
\hline & $\stackrel{ }{\theta}$ & $\stackrel{\theta}{\circ}$ & $\stackrel{\widehat{N}}{8}$ & $\frac{\infty}{\dddot{1}}$ & ఝึ? & $\overline{\mathfrak{g}}$ & & $\stackrel{\overbrace{}}{\oplus}$ & $\begin{array}{l}n \\
10 \\
10\end{array}$ & $\stackrel{\infty}{\text { nִ }}$ & $\stackrel{\infty}{+}$ & $\stackrel{\widetilde{O}}{\Theta}$ & $\stackrel{\widehat{s}}{-}$ & $n$ & $\stackrel{\vec{\oplus}}{\oplus}$ & $\stackrel{ \pm}{\stackrel{ \pm}{0}}$ & $\stackrel{m}{\dddot{m}}$ & $\stackrel{10}{8}$ & $\stackrel{8}{10}$ \\
\hline & $\bar{\theta}$ & ङั & ָี & $\stackrel{\ddagger}{\stackrel{\ddagger}{i}}$ & 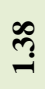 & ্ָ & $\stackrel{\overbrace{}}{\stackrel{\leftrightarrow}{\varphi}}$ & $\stackrel{\dddot{m}}{\Leftrightarrow}$ & & $\stackrel{\infty}{\stackrel{\infty}{\rightarrow}}$ & 7 & $\stackrel{\infty}{\stackrel{0}{\leftrightarrow}}$ & $\vec{m}$ & ले & 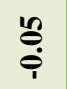 & ले & $\stackrel{\infty}{=}$ & $\stackrel{F}{g}$ & in \\
\hline & $\stackrel{9}{a}$ & ڤ̆ & ֶั: & ণ্ণি & $\stackrel{m}{=}$ & $\bar{m}$ & $\stackrel{7}{i}$ & $\stackrel{m}{\oplus}$ & $\begin{array}{l}\mathscr{3} \\
\stackrel{9}{i}\end{array}$ & 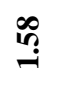 & if & 0 & نج & if & $\stackrel{\leftrightarrow}{0}$ & $\stackrel{?}{\stackrel{9}{0}}$ & $\stackrel{9}{=}$ & in & in \\
\hline & $\frac{m}{\theta}$ & 苛 & ֻัँ & $\stackrel{9}{\bar{\varphi}}$ & $\stackrel{m}{\rightarrow}$ & ले & 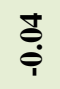 & 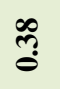 & है & بْ & พ & $\stackrel{\Xi}{8}$ & . & F & $\stackrel{t}{\Delta}$ & $\stackrel{0}{0}$ & ฉి & ஷִ & $\stackrel{10}{0}$ \\
\hline & $\vec{\theta}$ & : & กั้ & بِّ & $\Im$ & 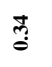 & : & 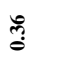 & : & $\stackrel{n}{=}$ & F & $\stackrel{\Xi}{0}$ & $\stackrel{?}{9}$ & ले & : & बें & $\stackrel{\leftrightarrow}{\leftrightarrows}$ & ঙ̆ & $\stackrel{f}{G}$ \\
\hline & $\frac{n}{10}$ & $\stackrel{\text { }}{\stackrel{0}{0}}$ & กิ & ஸ̆ & กี & సֶ. & 0 & త్ర & ì & in & $\stackrel{0}{+}$ & $\stackrel{\leftrightarrow}{\varrho}$ & I & $\stackrel{0}{+}$ & $\stackrel{\leftrightarrow}{\varrho}$ & $\stackrel{F}{e}$ & $\cong$ & $\stackrel{n}{1}$ & $\stackrel{t}{\stackrel{S}{8}}$ \\
\hline Average & & $\begin{array}{l}\infty \\
\stackrel{0}{0}\end{array}$ & $\stackrel{1}{\pi}$ & 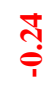 & ন্ড & త্: & $\stackrel{\mathscr{\infty}}{\stackrel{\infty}{i}}$ & ঙ্: & مُ & חִ & $\stackrel{\hat{f}}{\dot{\gamma}}$ & ๕ٌ & 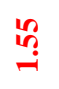 & in & 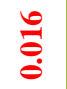 & గొల & $\stackrel{5}{\circ}$ & $\stackrel{m}{i}$ & 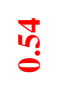 \\
\hline
\end{tabular}

\section{REFERENCES}

1. Al- Tawash B. S., Al- Lafta H. and Merkel B. 2013. Multivariate Statistical Evaluation of Major and Trace Elements inShatt Al-Arab Sediments, Southern Iraq, Journal of Environment and Earth Science, 3(11): 147-155

2. Ashraf etal. 2013. Soil Contamination, Risk Assessment and Remediation in Sceiano. M.C.H, Environmental Risk Assessment of Soil Contamination. INTECH.

3. Khwedim, K.H., Al-Anssari, H.R. and Al-Bassam, K. 2009. Study of distribution of some heavy metals in the soil of Basra city-south of Iraq", Iraqi Journal of Science, 50: 533 - 542. 
4. Reddy, M.R. and Govil, P.K. 2010. Assessment of heavy metal contamination in soils at Jajmau (Kanpur) and Unnao industrial areas of the Ganga Plain, Uttar Pradesh, India. J. Hazardous Mat., 174: $113-121$.

5. Bonito, M. D. 2005. Trace elements in soil pore water: a comparison of sampling methods. Ph. D., University of Nottingham. 263p.

6. Hooda, P.S. 2010.Trace Elements in Soils. Blackwell Publishing Ltd. 618p.

7. Kabata-Pendias, A. and Mukherjee, A.B. 2007. Trace Elements from Soil to Human. SpringerVerlag Berlin Heidelberg, 561.

8. Taylor, S.R. and McLennan, S.M. 1985. The continental crust: its composition and evolution, Blackwell, Oxford.

9. Nesbitt, H.W. and Young, G.M. 1982. Early Proterozoic Climate and Plate Motion Inferred from Major Element Chemistry of utites. Nature, 299: 715 - 717.

10. Drever, J. I.1997.The geochemistry of natural water, surface and ground water environments, $3^{\text {rd }}$ ed. Prentice Hall, USA, 436p.

11. Aubert, H. and Pinta, M. 1977. Trace elements in soils, Developments in soil science, Elsevier scientific publishing Co., Amsterdam, 395.

12. Zhang, H. 2007. Classification of irrigation water quality.F-2402. Oklahoma state university. Dep. of Agric. cooperative extension fact sheets.

13. Kabata-Pendias, A., Dudka S., Chlopecka A., Gawinowska T. 1992. Background levels and environmental influences on trace metals in soils of the temperate humid zone of Europe. In: Adriano DC (ed) Biogeochemistry of trace metals. Lewis Publ, Boca Raton, pp 19-60

14. Hawkes, H. E. and Webb J. S. 1962. Geochemical characteristics of the elements. In Geochemistry and mineral exploration, Harper \& Row, 415P

15. Alloway, B.J. 1995. Heavy metals in soils. 2nd ed., Blackie Acad, London.

16. Kaplan, D.I., Knox S.A. and Coffey C. 2002. Reduction of contaminant mobility at the TNX outfall delta through the use of apatite and zero-valent ion as soil amendments (U). WSRC-TR2002-00370, Rev. 0, Westinghouse Savannah River Company, Aiken, SC.

17. Waaren, L. A. and Haack E. A. 2001. Biogeochemical controls on metal behavior in freshwater environments. Earth Science Reviews, 54: 261-320.

18. Kabata-Pendias, A. and Pendias, H. 2001. "Trace Elements in Soils and Plants", CRC Press LLC, Boca Raton,Florida, USA.

19. Kabata-Pendias, A. and Sadurski, W. 2004. Trace elements and compounds in soil. In: Merian E, Anke M, Ihnat M, Stoepppler M (eds) Elements and their compounds in the environment, WileyVCH, Weinheim, $2^{\text {nd }}$ ed., $79-99$.

20. Weaver, C.E. and Pollard, L. 1974. The Chemistry of Clay Minerals, Elseiver Scientific Publication Co., New York,213 P.

21. Thomilson, D.C., Wilson, D.J., Harris, C.R. and Jeffrey, D.W. 1980. The problem in heavy metals in estuaries and the formation of pollution index. Helgol. Wiss. Meeresunlter. 33: $566-575$.

22. Caeiro, S., Costa, M, H. and Ramos, T.B. 2005. "Assessing Heavy Metal Contamination in Sado Estuary Sediment:An Index Analysis Approach”, Ecological Indicators, 5: 151-169

23. Blaser, P., Zimmermann, S. and Luster, J. 2000. "Critical Examination of Trace Element Enrichments andDepletions in Soils: $\mathrm{As}, \mathrm{Cr}, \mathrm{Cu}, \mathrm{Ni}, \mathrm{Pb}$, and $\mathrm{Zn}$ in Swiss Depletions in Soils: As, $\mathrm{Cr}, \mathrm{Cu}, \mathrm{Ni}, \mathrm{Pb}$, and $\mathrm{Zn}$ in SwissForest Soils", The Science of the Total Environment, 249: 257-280

24. Golchert, B., Landsberge, S. and Hopke, P.K. 1991. "Determination of Heavy Metals in the Rock River (Illinois) through the Analysis of Sediment", J. Radioanalyt. Nucl. Chem. Articles, 148(2): 319-337

25. Hernandez, L., Probst, J.L. and Urich, E. 2003. "Heavy Metal Distribution in some French Forest Soils, Evidence for Atmospheric Contamination", Sci, Total Environ. 312(1-3): 195-219

26. Fong, F.T., Chee, P.S., Mahmood, A.A. and Tahir, N.M. 2008. "Possible Source and Pattern Distribution of Heavy Metals content in urban soil at Terengganu town center", Malay. J. Anal. Sci. 12: 458-467

27. Al-Bassam, K. S. and Yousif, M. A. 2013. geochemical distribution and background values of some minor and trace elements in Iraqi soils and recent sediments. Iraqi Bulletin of Geology and Mining, 10(2): 109-156. 